\title{
Currere, Unexpected Journeys, and Unplanned Destinations in Academia
}

\author{
Susan R. Adams
}

Butler University

\begin{abstract}
A sudden change of teaching placements forced my return to graduate school at the age of 40. Transformative graduate school learning resulted in the completion of a Ph.D. and earning a tenure track position in teacher education. This essay uses Pinar's four steps of currere provide a lens to examine the past, look toward the future, take opportunity to look backward to the past while examining the present, and then re-enter the present. Mezirow's transformative adult learning theory lends guidance for understanding why older adults may be uniquely poised to navigate successfully the complex maze of academia.
\end{abstract}

Keywords: transformative adult learning theory; currere; doctoral studies

Susan R. Adams (Ph.D) is Assistant Professor of Middle/Secondary in the College of Education at Butler University. A former secondary ESL teacher and coach in Indianapolis Public Schools, Susan's research, and professional interests include race, critical pedagogies, equity, and academic success for all students. Prior to earning her tenure track position, she served as the director and lead instructor for Project Alianza, a USDOE Title III National Professional Development grant. Susan is a Critical Friends Group Coach with the School Reform Initiative, a site leader of the Hoosier Writing Project, and the current co- Faculty Development Fellow at Butler University.

Email: sradams@butler.edu

Brock Education, 24(1), Fall 2014, pp. 4-10. 


\section{Introduction}

In this essay, Pinar's (2004) four steps of currere (the regressive, the progressive, the analytical, and the synthetical) provide a lens through which I:

- Examine my own past as a rich data source (the regressive)

- Look toward the future, toward what is possible (the progressive)

- Take opportunity to look backward to the past while examining the present (the analytical), and then

- Re-enter the present (the synthetical).

In addition, Mezirow's (1991) transformative adult learning theory lends guidance for a "complicated conversation" (Pinar, 2004) with myself as "an ongoing project of selfunderstanding in which one becomes mobilized for engaged pedagogical action" (p. 37) toward understanding how and why older adults may be uniquely poised to navigate successfully, the complex maze and rigors of academia as they hearken to the call to teaching in midlife.

\section{My Story: The Regressive Glance Backward}

In 1985, I graduated with a BA in Spanish and a secondary teaching license. I entered the teaching force zealously committed to honing my pedagogy and to deepening my language skills as I shaped young lives. Teaching high school students excited and energized me. Although each was shaped with familiar high school rituals and rhythms, they were also spiced by the energy adolescent learners exude from their very pores. In those early years, my husband's law school friends condescended to me, bending from their imagined lofty heights, and sympathetically cooing, "Oh, you teach. Isn't that special?" but I could imagine no more important work and no higher calling.

In those days, teachers were required to earn a master's degree within the first five years of licensure, so almost immediately I enrolled in a graduate program at my alma mater in education courses which allowed me to study once again with professors I had much admired and respected in my undergraduate days. Although it meant driving 70 miles each way several nights a week, I was overjoyed to return to Indiana State to engage with Dr. Chris Buethe and the other grad students to connect educational theory to our daily practice of teaching.

At the end of an intense year of teaching and graduate studies, I lingered after class on the last night, hoping for a quiet moment alone with Dr. Buethe. I shared with him the news that I was expecting my first child in the fall, which would necessitate pushing the pause button on completing my master's degree. Dr. Buethe congratulated me warmly but stopped me as I turned to go. As he gripped my shoulder, he leaned down and emphatically uttered a statement which lodged permanently in my brain and completely rocked my world for years to come. "Listen," he said, "I think you are a pretty good teacher right now, and I believe you will grow to become a great teacher one day. But some day, I think you are going to want to do what I do: teach new teachers." I was speechless with astonishment in that moment and even more deeply touched when I received a letter in the mail a few days later in which he reiterated in writing his conviction that I would find my way into teacher education. I tucked the letter away, left the master's degree unfinished for the moment, and spend the next ten years raising my children.

I have no regrets whatsoever for choosing to focus on my own kids and am grateful to have been able to cobble together odd part-time teaching jobs that allowed me to be available, involved and closely engaged with them while they were young. During those years I told myself 
and anyone who asked that I was at peace with having completed 30 hours toward the masters' degree without finishing, but in the back of my mind, a vague sense of unfinished business haunted me. However changing circumstances required a new plan: as I turned 40 and as my kids entered middle school, the tragic end of my marriage forced me to seek a new full time teaching position-a tricky proposition given that my teaching license was expired at the time. When I was offered a teaching position outside my licensure expertise in a high school English as Second language (ESL) classroom, I headed back to graduate school-first to renew my teaching license, and then to earn an add-on license in ESL.

If I wanted to keep my new ESL teaching position, I had to complete 18 hours of graduate courses to earn the ESL license, and I had to do it quickly. I enrolled in the School of Education at Indiana University at Indianapolis, where I knew no one. I was at first a bit queasy as I enrolled in my first two courses, Sociopsycholinguistics in the K-12 Classroom and Second Language Acquisition Theory. These titles were intimidating, and it seemed like a long time since I had been asked to read, write, think, and talk about such lofty concepts at the grad school level. How was I going to manage these academic demands while I simultaneously raised three middle-school aged kids, mourned the death of my marriage, and began a new job in a struggling high school, which in itself felt like being flung into the deep end of the pool? I took a deep breath and headed to my first class.

The group of students I met there astonished me. The educators in my classes-nearly all women-covered the spectrum, from nervous, newly minted beginning teachers to confident looking thirty-somethings to middle aged women like me. Nearly all of us had risen at 5AM, cared for our families, and taught a full day of school before heading to this intensive class meeting twice a week for three hours at a time. Several of us were enrolled in two courses like this simultaneously, meaning we were there four nights a week for six weeks while our schools were still in session. Occasionally one of us arrived with a child in tow when childcare fell through. Our professors and classmates were sympathetic and patient, understanding what a distraction it was to wonder what my 12-year-old might be up to in the hallway outside our classroom.

What should have been a miserable time of overload was instead for me a joyous awakening. After having taught beginning Spanish for many years, it was refreshing to see language learning from a completely different perspective. Being in the classroom each day with language learners provided me with rich schematic connections to the research and theoretical texts we read and discussed each night in class. I began to observe carefully my English language learners' reading and writing progress each day, making mental notes of scenarios I could share later in class as my conceptual understandings of their learning deepened. Inexorably, my teaching began to change, reflecting my shifting pedagogical stance. When I completed the ESL licensure program, I decided I needed to keep going and finish the master's degree, which I imagined would provide a sense of closure and satisfaction.

In addition to seeing rich connections between grad school theories and my classroom practice, I was gratified to find my professors welcomed my exuberant classroom contributions, valued my thinking, and believed my writing was strong. Honestly, at first I really thought they were simply nice, perhaps kindly trying to encourage me so I could finish the program. But to my amazement, at the end of my final master's course, one professor, who had coincidently also taught my very first class, suggested I try to get my final paper published in a scholarly journal. And even more surprising, she asked if I had ever considered earning a Ph.D. I gasped, "Of course I have! But what am I supposed to do? Quit my teaching job, uproot my three kids, and move to Bloomington to live on a meager grad assistanceship?!" Beth, the professor, understood and agreed that this was an unlikely and unrealistic scenario for someone like me. 
While Dr. Buethe had confidently predicted when I was only 24 that I would end up as an assistant professor in a teacher education program, at the time, though flattered by his encouragement, I could see no way for that prophecy to come true. In addition, I was still excited to be a teacher and felt I still had new depths of my practice to explore and to discover. My professional life was neatly bound, shaped and defined by the predictable and comforting course set by the assumptions, rhythms, and rituals the currere (Pinar, 2004) of school provides, or so I thought until Beth emailed a group of women a few months later with an intriguing invitation: she believed she had negotiated approval for a special Ph.D. program for a cohort of practicing teachers in our city-one that would not require us to quit our jobs or drive relentlessly to Bloomington. Though in retrospect, I realize that we did not remotely understand the personal or professional implications of the decision, a group of about 10 women, mostly middle aged, experienced educators took the leap of innocence and faith together and started down the doctoral degree path just as I turned 46.

\section{The Progressive View from the Doctoral Pathway}

In an interesting turn of coincidence, as I began my doctoral program, I also simultaneously left my K-12 instructional coaching job to begin a new role at Butler University, a nearby liberal arts university, in a grant-funded, temporary position. This new opportunity allowed me to delve into my newly discovered interest in supporting mainstream teachers to improve access and outcomes for K-12 English language learners in urban secondary schools. I also was suddenly working amongst tenured and tenure-track teacher education faculty members. My original plan at the conclusion of the temporary job was to return eventually to my school district, perhaps as a curriculum director. Gradually what eluded my understanding in the early months of my studies suddenly dawned on me clearly; a Ph.D. in education was preparing me for one thing, and one thing only: a permanent, tenure track position in a teacher education program. And just as suddenly, I remembered Dr. Buethe's prediction and realized that teacher education was my new goal, just as he had foreseen.

This is the moment in which my "complicated conversation" (Pinar, 2004) with myself as "an ongoing project of self-understanding in which one becomes mobilized for engaged pedagogical action" (p. 37) consciously began. Whereas the masters' courses deepened my conceptual and theoretical understandings, and prepared me for leadership roles in my K-12 schooling, in the doctoral program, I was so enamored by the joyous sensation of digging into theory and practice I gave little consideration to the degree's intended purposes. Ignorantly and innocently, I jumped into my doctoral studies for the pure pleasure of discovery and of vigorous, rigorous academic work with little thought for how it would change me. Slowly I grew to understand I was being trained to listen, read, write, speak, think, and respond in new, mostly critical ways of seeing myself and the world. I was being shaped into an academic, a member of the academy, an identity I never expected to claim.

\section{The Analytical: Looking Forward, Looking Backward}

Understanding my emerging identity as an academic pushed me to set my sights on a permanent, tenure-track position I hoped would be available at just the right time at Butler University. I realized, too, that being a middle-aged person was now a massive advantage, rather than the disability it sometimes seems to be elsewhere. Wherever I went, people assumed I already was a seasoned, experienced, gainfully employed academic; no one expected someone my age to be a doctoral student. Though I always stated my status clearly to others, I decided to act as if I 
already had the identity and the job I wanted. Seeing my new goal clearly allowed me early to become a functioning member of the academic discourse community (Gee, 2000), to begin to do the research, writing, and scholarly presentation work that academics do, and to give my colleagues a reason to imagine my future alongside them in that tenure-track position I hoped to earn. The increased workload and self-imposed expectations were stressful, constituting a staggering demand on top of my doctoral studies and dissertation writing; I recursively returned in memory to that crystalized moment with Dr. Buethe to inspire me and to give me confidence as I reached forward to the future identity I envisioned earning and taking on.

\section{The Synthetical: Back to the Present Moment}

I am grateful to find myself now in that tenure track position I had visualized though just as before, few university colleagues expect a woman of my age (51) to be a third-year assistant professor. The reality is that being middle aged with young adult children who are (mostly) taking care of themselves is yet again an unexpected advantage over my younger colleagues. I am less distracted and exhausted by the demands of parenting, free to focus my energies on my teaching, scholarship and service as I pursue tenure. Conference travel and long bouts of writing do not pose difficulties for my family these days. And perhaps most importantly, what I have learned about myself along the way gives me immense confidence to take risks, to take on new challenges, and best of all, to do the scholarly work I want to do, rather than to meekly and timidly do whatever is most likely to win me the approval of others just to earn tenure.

\section{Conclusion}

As Tisdell and Tolliver (2009) state eloquently in their retrospective of Mezirow's (1991) work, "New knowledge cannot 'become you' simply through engaging rationality. It has to get into our hearts, souls, and bodies and into our interactions with others in the world" (p. 93). Mezirow's (1991; 2000) work on transformative learning theory provides language and structure for me to make meaning of my journey. In the table below (Figure 1), Mezirow's (2000) ten phases of learning inherent in the transformative process are shown in the first column; my own life connections and experiences are identified and aligned in the second column:

The recursive push and pull process of currere (Pinar, 2004) creates opportunity to retrospectively examine my experiences and my actions in light of my new learning, thereby changing my sense of self in the present, as well as pushing the boundaries of my imagination for my future. Transformative learning in the middle years of my life has kept my mind, and my heart feeling much younger than I expected to feel at this stage in my life. Unlike many of my age mates, I believe I am handling the transitions of this middle life stage with little trepidation because I am armed with new work, fresh perspectives, intellectual energy, and an evolving personal and professional identity. As O'Sullivan and O'Conner (2002) have stated,

[Transformative Learning] involves our understanding of ourselves and our selflocations; our relationships with other humans and the natural world; our understanding of the relations of power in interlocking structures of class, race and gender; our body awareness, our visions of alternative approaches to living; and our sense of the possibilities for social justice and peace and personal joy (p. 17).

Brock Education, 24(1), Fall 2014, pp.4-10. 
I continue to find that attending to my own learning and to the joys inherent in transformative learning are their own reward and pay big dividends personally and professionally. Rather than resignedly settling for the way things are, or worse, descending into a mid-life crisis, middle age is the perfect time to embrace new learning and to see what journeys await us when we are open to new possibilities and transformative learning.

Figure 1 :Mezirow's Ten Phases of Transformative Learning (2000, p. 19)

\begin{tabular}{|c|c|}
\hline $\begin{array}{l}\text { Mezirow's } 10 \text { Phases of Transformative } \\
\text { Learning }\end{array}$ & $\begin{array}{l}\text { Life Events and Actions that Correspond } \\
\text { to the } 10 \text { Phases of Learning }\end{array}$ \\
\hline 1. A disorienting dilemma & $\begin{array}{l}\text { Failure of the marriage; new teaching job; } \\
\text { new field of study for licensure }\end{array}$ \\
\hline 2. Self-examination & $\begin{array}{l}\text { New learning provokes consciousness of prior } \\
\text { teacher identity and commitments }\end{array}$ \\
\hline 3. A critical assessment of assumptions & $\begin{array}{l}\text { Reading, class discussions, and writing from } \\
\text { critical perspectives pushed me to notice and } \\
\text { name my own assumptions. }\end{array}$ \\
\hline $\begin{array}{l}\text { 4. Recognition of a connection between } \\
\text { one's discontent and the process of } \\
\text { transformation }\end{array}$ & $\begin{array}{l}\text { Awareness of misalignment between my } \\
\text { assumptions and teaching commitments } \\
\text { created a desire for integrity and wholeness, } \\
\text { sparking changes in my thinking, my } \\
\text { approaches, and my commitments. }\end{array}$ \\
\hline $\begin{array}{l}\text { 5xploration of options for new roles, } \\
\text { relationships, and action }\end{array}$ & $\begin{array}{l}\text { I shifted away from a compliant teacher } \\
\text { identity, now seeing myself as an advocate, a } \\
\text { critical thinker, and a critical theorist. I } \\
\text { asserted myself more in conversations, } \\
\text { meetings, and decisions. }\end{array}$ \\
\hline 6. Planning a cour & $\begin{array}{l}\text { I became aware that the doctoral degree was } \\
\text { preparing me for work in higher education } \\
\text { and for an identity as a scholar. }\end{array}$ \\
\hline $\begin{array}{l}\text { 7. Acquiring knowledge and skills for } \\
\text { implementing one's plan }\end{array}$ & $\begin{array}{l}\text { I made a conscious decision to work closely } \\
\text { with a mentor who took an active role in } \\
\text { preparing me for academia through } \\
\text { discussions, shared readings, conference } \\
\text { presentations, career counseling. }\end{array}$ \\
\hline 8. Provisional trying of new roles & $\begin{array}{l}\text { I made a conscious decision to act as if I } \\
\text { already had the job I hoped to earn later. }\end{array}$ \\
\hline $\begin{array}{l}\text { 9. Building competence and self-confidence } \\
\text { in new roles and relationships }\end{array}$ & $\begin{array}{l}\text { Taking risks, accepting new leadership } \\
\text { responsibilities, and participating in scholarly } \\
\text { writing and reviewing gave me experience } \\
\text { and confidence. Positive feedback from others } \\
\text { reinforced this decision, allowing me to do } \\
\text { more and to go deeper. }\end{array}$ \\
\hline
\end{tabular}


10. A reintegration into one's life on the basis of conditions dictated by one's new perspective
Applying for, earning, and beginning the fulltime, tenure-track position were relatively easy transitions given the years of gradual integration I had already experienced, allowing me to carry my new learning perspectives into my work immediately, rather than waiting for tenure.

\section{References}

Gee, J. (2000). Identity as an analytical lens for research in education. Review of Research in Education, 25, 99-125.

Mezirow, J. (1991). Transformative dimensions of adult learning. San Francisco: Jossey-Bass Publishers.

Mezirow, J. (2000). Learning to think like an adult: Core concepts of transformation theory. In Jack Mezirow and Associates (Ed.), Learning as transformation: Critical perspectives on a theory in progress (pp. 3-34). San Francisco, CA: Jossey-Bass.

O'Sullivan, E., Morrell, A., \& O'Conner, M. (2002). Expanding the boundaries of transformative learning. New York: Palgrave.

Pinar, W. (2004). What is curriculum theory? Hillsdale, NJ: Lawrence Erlbaum.

Tisdell, E. J., \& Tolliver, D. E. (2009). Transformative approaches to culturally responsive teaching: Engaging cultural imagination. In J. Mezirow, E. W. Taylor, \& and Associates, Transformative learning in practice: Insights from community, workplace, and higher education (pp. 89-99). San Francisco: Jossey-Bass. 